\title{
Transparency in the Municipal Public Management: An Evaluation of Rio Grande do Sul State's Municipalities
}

\author{
Andressa Petry Müller ${ }^{1} \&$ Nelson Guilherme Machado Pinto ${ }^{2}$ \\ ${ }^{1}$ Center for Social and Human Sciences, Federal University of Santa Maria, Santa Maria, Rio Grande do Sul, Brazil \\ ${ }^{2}$ Administration Department, Federal University of Santa Maria, Palmeira das Missões, Rio Grande do Sul, Brazil \\ Correspondence: Andressa Petry Müller, Center for Social and Human Sciences, Federal University of Santa Maria, \\ Santa Maria, Avenue Roraima, 1000, Rio Grande do Sul, Brazil. Tel: 55-3220-8000.
}

Received: April 19, 2021

Accepted: May 20, 2021

Online Published: January 5, 2022

doi:10.5430/ijba.v13n1p1

URL: https://doi.org/10.5430/ijba.v13n1p1

\begin{abstract}
The objective of the present study is to determine the transparency level of Rio Grande do Sul state's municipalities, identifying the variables that explain it. This is a documental and quantitative research, observing the most recent information disclosed in the state's transparency websites, identifying if the data disclosure is correct, through the Municipal Public Management's Transparency Index, as well as the regression analysis and descriptive statistics. In this way, it is possible to observe that most state's municipalities present an average level of transparency. Besides, it was observed that, from the eleven socioeconomical variables that were analyzed, only five are capable of influencing the transparency index. Therefore, many measures must still be adopted by the state's municipal managements, so that they enforce the Access to Information Law and fulfill all of the aspects that come from the transparency.
\end{abstract}

Keywords: transparency, access to information law, municipalities

\section{Introduction}

The society is increasingly participative, looking for information about the actions that the government carries out, which regards everyone, of public nature and collective attention. In this way, there are common necessities among the subjects, which must be addressed. Ribeiro et al. (2011) highlight that, through the communication that citizens establish with the local public administration, there is collaboration to meet those requests, mainly in relation to the socioeconomical issues.

Thus, in order to ensure public management in a correct way, being it analyzed, supervised, or carried out, there is the governance in the public aspect. It aims at guaranteeing correspondence with collective expectations, to promote citizens participation and an appropriate disclosure of information, aiming at monitoring the government acting, ensuring the conduction of an efficient management that is capable of meeting what is required (MELLO; OLIVEIRA; PINTO, 2017).

In addition, there is the transparency, which aims at contributing to the control and improvement of the public resources' management, helping in the political issues, providing a better coverage of democracy. It also has an important role against deviations and bad use of monetary assets, mainly for relying on society's collaboration in these issues, resulting in confidence to the population concerning what is being carried out.

Transparency is also established by means of the Access to Information Law (Lei de Acesso à Informação - LAI), instituted by Law $\mathrm{n}^{\circ} 12.527$, related to transparency, which aims at contributing to the access to public information, guaranteeing the participation of all the citizens, in a way that they can get involved with the decisions that are undertaken (MICHENER; MONCAU; VELASCO, 2014). In respect to the law that enacts this action, in its 5th article it is stated that the State must enable everyone to the information access concession, through determined and efficient means, in an understandable, accessible, and trustable way (BRASIL, 2011).

Thus, it was implemented the requirement for the government representatives to carry out the data dissemination, which are of social importance, through the internet, and they must be exposed even if no request for such a reference is made (COMIN et al., 2016). It is understood that transparency is the availability of information for all, but this is not enough, the accessibility and participation are also necessary. The accessibility regards the possibility 
of all the subjects involved, which demonstrate interest in the information, to be able to use it, while the participation is the proportion that the public management allows the interested subjects to relate with them (PIÑA; AVELLANEDA, 2019).

To this extent, to evaluate all the published information, actions are taken to measure the adoption of transparency through indexes. In this context, the transparency index emphasizes the importance of granting data in a correct and objective way, trying to observe the citizens' impositions, and to make all the undertaken activities available for everybody's access and in a transparent way (MOLINARI; CLAZER, 2015).

Thus, the application of the transparency index is essential, which makes the accountability more concrete and objective, in which a control of the available amount is carried out, being possible to help society in the best way, focusing on what people demand. Such index also adds value to people that have access to information, being a qualified mechanism to achieve a common good (MOLINARI; CLAZER, 2015).

However, information is not always available for citizens, mainly when it regards the municipalities, as what happens in the municipal public management in Rio Grande do Sul, which lacks data disclosure, do not providing an environment of transparency composition on its portals (VISENTINI; SANTOS, 2019). Besides, regarding the municipal issue, transparency and information access are crucial for promoting a greater participation of the citizens in the decision-making, because they tend to monitor more closely the information concerning the reality they are inserted in (SANTOS; ROCHA, 2019).

Therefore, the present study aims at determining the transparency level of the municipalities of Rio Grande do Sul state, identifying the variables that explain it. This analysis is essential for the necessity of carrying out the analysis of Rio Grande do Sul's municipalities, to understand if they are being transparent, which may influence their transparency and the disclosure of their information. Besides, the present study brings a wider analysis of transparency, analyzing all the municipalities of Rio Grande do Sul, observing several aspects related to data disclosure in the municipal public scope, contemplating the influence of a significant number of variables that impact the transparency levels. Thus, the main contribution of the present research is the methodological advance, through a greater quantification on the analyzed sample, besides offering a current framework concerning transparency in Rio Grande do Sul's municipalities.

Thus, the study the quantitative method will be adopted, based on the analysis of dimensions that represent transparency, analyzed by a binary evaluation, and subsequently, descriptive statistics and multiple linear regression will be performed. Therefore, the present study is structured in addition to this introduction in section two that concerns the literature review, in section three the method is addressed, in the following, the results, and finally, in section four the conclusions are addressed.

\section{Literature Review}

Transparency is characterized, according to Zuccolotto and Teixeira (p. 245, 2014), as a "mechanism for the reduction of the corruption level or the improvement in the economic performance", being the most notorious way of disclosing actions and situations found in the administrative scope (MOLINARI; CLAZER, 2015). It is also convenient to the access of public information, providing a more contemporaneous model to guarantee data, holding importance and value about what is disclosed (FRANCO et al., 2014; MOLINARI; CLAZER, 2015).

In this context, transparency is something legally required in Brazil, and there is supervision and control of what is carried out by means of responsible structures and also by means of people, in which data coverage guarantees that the actions carried out by governments are published in an open and understandable way (MOLINARI; CLAZER, 2015). Its importance has grown even more through the Federal Constitution, which demands the disclosure of what is carried out, given that in Article 70, through the 19th Constitutional Amendment from 1998, it is required that every public or private individual and legal entity present an accountability, which is responsible for monetary values or possessions of public stamp or attributed to the Union (BRASIL, 1988). Thus, from that, information acquisition became one of the fundamental elements to promote citizenship, because, through it, there is more inspection, which is possible by means of the population, which culminates in the adoption of more transparent acts (GOMES; FREIRE; SALES, 2017).

In the same way, the Access to Information Law, $\mathrm{n}^{\circ} 12.527$, which promulgates transparency, sanctioned by the republic presidency on November 18th, 2011, establishes the institutionalization of original tools and tasks, also guaranteeing the improvement of procedures that are already adopted, enabling an appropriate reach of public data. Thus, it is enforced the necessity of every municipality that has more than ten thousand inhabitants to publish its information, providing its free access on the locality's website (MACEDO et al., 2020). 
In this way, there are two different types of transparency, which the first, called active transparency, refers to the publication of data that are relevant for all the society, and must be done in advance and in a frequent way by the public structures and institutions. The second type of transparency is called passive, which is the commitment of considering the information requirements made by the citizens, and the answers must be provided, exposing what was requested (BARROS et al., 2017).

In addition to that, it can be noticed that transparency helps extinguishing the questionable and inaccessible aspect, helping the containment of corruption and abuse of power, allowing quality for the public policies that are adopted, also reducing the insufficiency in the public aspect, because the governors, in many situations, adopt deliberations that only guarantee the private privilege, being possible to intervene in the social and economic perspectives, being the disclosure of clarifications between government and society crucial (TEJEDO-ROMERO; ARAUJO, 2018; FRAGA et al., 2019; ZUCCOLOTTO; TEIXEIRA, 2019; FRANKE et al., 2020).

Measuring the transparency is extremely important to identify if it is being exercised, providing the evaluation and verification by the population regarding what the Public Administration is doing, interrupting the administrative silence practice (PIRES et al., 2013). To this end, there are the indexes, which are used to measure aspects, helping to indicate, expose or point something specific, being possible to represent a numeric value that represents a simple or a complex structure, employing appropriate scientific criteria and resources, functioning as a mechanism that helps in the deliberations to be carried out (SICHE et al., 2007).

In this context, the transparency portal arose, created in 2004, which has the intent of releasing the citizens' access to consult the use of the public goods, being possible to supervise and certify if such resources are being properly employed (CGU, 2019). With such a tool, it is possible to notice when a government goes through difficulties, because with all the available information, it is easy to understand and to interpret, mainly when it regards economic issues (VISENTINI; SANTOS, 2019).

In the same way, something that facilitates the access to information made available by the government are the Information and Communication Technologies (ICT), which enable a positive relation between citizen and government, in a more egalitarian and communicative way. This results in granting information on websites in a simple way and understandable for all, facilitating the verification of information that the citizen seeks, which contributes to their participation in the decision-making process (ARAÚJO; MAIA, 2014; LOBO; MAIA, 2015).

\section{Method}

The present study is a descriptive research, which is established as the function to determine the properties of an investigation demand, helping during the development of the study (HAIR JR. et al., 2005; GERHARDT; SILVEIRA, 2009). It is also a documental research, which aims at analyzing documents that already exist and are significant about the subject (HAIR JR. et al., 2005).

The research may still be classified as quantitative, which represents the approach to measure data, in which numbers are used to characterize the specificities of a given subject. It may also represent the approach to assume the establishment of the attribution of each variable and the associations among them, in which presuppositions to be verified amidst the investigation of the taken information are employed (HAIR JR. et al., 2005; GABRIEL, 2014).

In addition to that, the sample of the present study is composed by all the 497 municipalities from Rio Grande do Sul state, where an analysis was carried out in each municipality. The investigation was carried out taking into account the most recent information available on the municipal transparency portals, because data are constantly updated.

Thus, to achieve the objective of the present study, secondary data were collected, and the information and necessary elements were sought on the city hall's websites of the 497 municipalities from Rio Grande do Sul state, taking into consideration the evaluation of places that have less than 10 thousand inhabitants, even though their disclosure is not mandatory. That way, the use of the documental research and analysis technique is employed, which, for Cechinel et al. (2016), is determined by the consultation and investigation of documental registers, and starts from their verification, and then, their analysis.

From this, the evaluation of the transparency level was carried out considering the Transparency Index of the Municipal Public Management, based on Cruz et al. (2012) and Pires et al. (2013)'s studies. Thus, the information available on those municipalities' websites was analyzed in the period from July to September 2020, outlined on Table 1. 
Table 1. Transparency index of the municipal public management's dimensions

\begin{tabular}{|c|c|c|c|}
\hline Item & Dimensions & Variables & $\begin{array}{l}\text { Dimension } \\
\text { representation }\end{array}$ \\
\hline \multirow{8}{*}{ D1 } & \multirow{8}{*}{$\begin{array}{l}\text { Municipality's } \\
\text { information }\end{array}$} & Positions & \multirow{8}{*}{15 points $=20 \%$} \\
\hline & & Staff & \\
\hline & & Position in Commissions or Rewarded roles & \\
\hline & & Data regarding the municipality & \\
\hline & & News regarding the municipality & \\
\hline & & Office hours & \\
\hline & & Contact & \\
\hline & & Useful phone numbers & \\
\hline \multirow{5}{*}{ D2 } & \multirow{5}{*}{ Municipal legislation } & Ordinary laws & \multirow{5}{*}{$\begin{array}{l}5 \text { points } \\
6,67 \%\end{array}$} \\
\hline & & Complementary laws & \\
\hline & & Decrees & \\
\hline & & Municipal resolutions & \\
\hline & & Municipality’s projects & \\
\hline \multirow{7}{*}{ D3 } & \multirow{7}{*}{ Financial information } & $\begin{array}{l}\text { Balance sheet, balanced budget, and financial } \\
\text { statements }\end{array}$ & \multirow{7}{*}{$\begin{array}{l}10 \text { points } \\
13,33 \%\end{array}$} \\
\hline & & Revenues & \\
\hline & & Expenses & \\
\hline & & Properties & \\
\hline & & Vehicles & \\
\hline & & Payroll & \\
\hline & & Rates and tickets & \\
\hline \multirow{4}{*}{ D4 } & \multirow{4}{*}{$\begin{array}{l}\text { Information concerning } \\
\text { agreements, bids and public } \\
\text { notices }\end{array}$} & Bids & \multirow{4}{*}{$\begin{array}{l}5 \quad \text { points } \\
6,67 \%\end{array}$} \\
\hline & & $\begin{array}{l}\text { Public notices for selective processes (public } \\
\text { tenders) }\end{array}$ & \\
\hline & & Call for individuals approved in public tenders & \\
\hline & & Established agreements & \\
\hline \multirow{4}{*}{ D5 } & \multirow{4}{*}{ Society participation degree } & Ask for information reports by period & \multirow{4}{*}{$\begin{array}{l}5 \text { points } \\
6,67 \%\end{array}$} \\
\hline & & Amount of submitted request & \\
\hline & & Request topic & \\
\hline & & Request date and answer date & \\
\hline \multirow{5}{*}{ D6 } & \multirow{5}{*}{$\begin{array}{l}\text { Information concerning the } \\
\text { management of each specific } \\
\text { area of the municipality }\end{array}$} & Phone number & \multirow{5}{*}{$\begin{array}{l}7 \quad \text { points } \\
9,33 \%\end{array}$} \\
\hline & & Email & \\
\hline & & Address & \\
\hline & & Opening hours & \\
\hline & & Team & \\
\hline \multirow[t]{2}{*}{ D7 } & \multirow{2}{*}{$\begin{array}{l}\text { Citizens Information Service - } \\
\text { CIS }\end{array}$} & $\begin{array}{l}\text { Area dedicated to the electronic system of the } \\
\text { CIS (e-CIS) }\end{array}$ & \multirow[t]{2}{*}{$\begin{array}{l}5 \text { points } \\
6,67 \%\end{array}$} \\
\hline & & Data request form & \\
\hline
\end{tabular}




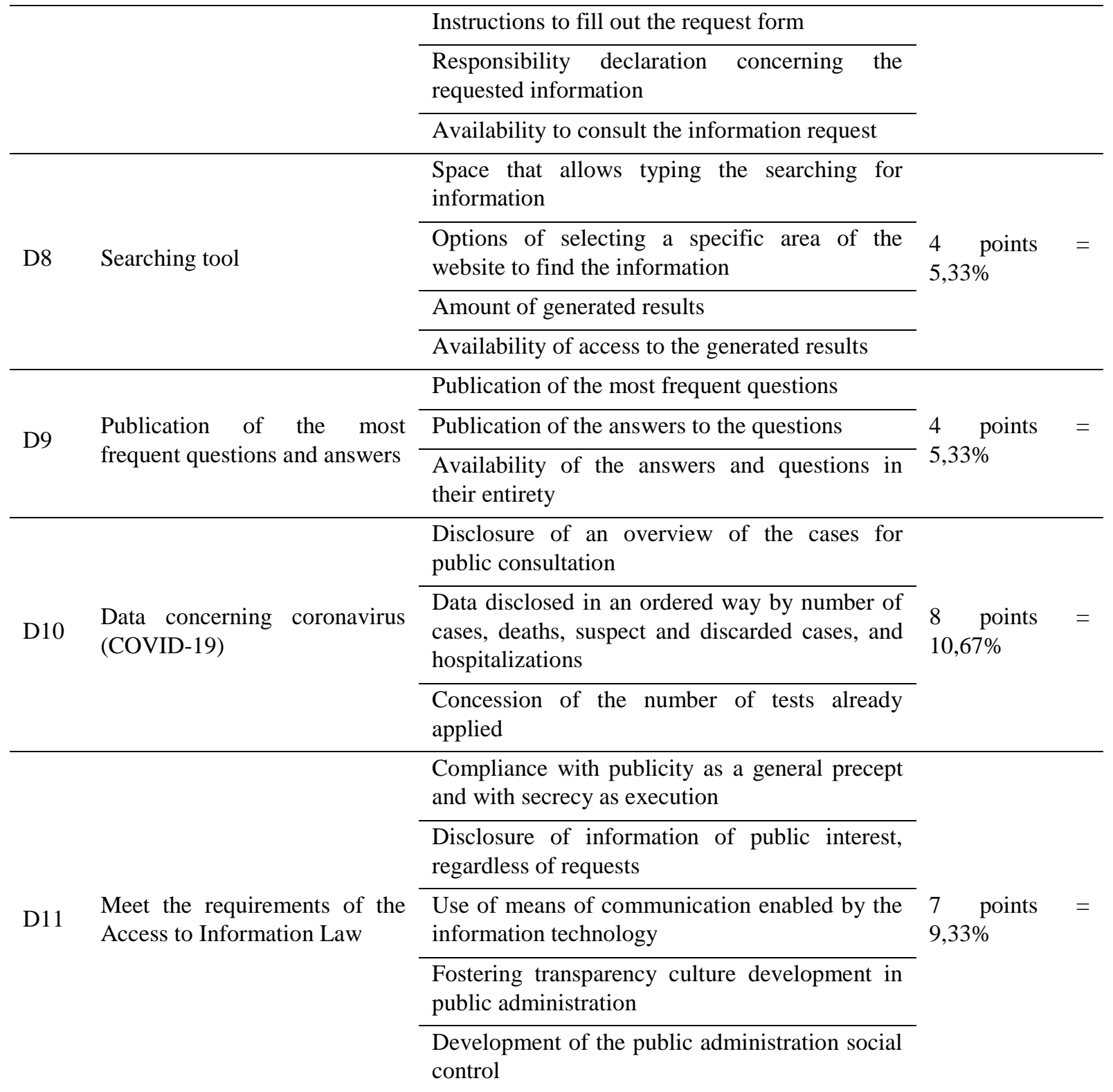

Source: Adapted from Cruz et al. (2012); Pires et al. (2013); Raupp and Pinho (2020).

That way, the research approached issues concerning the municipality's general information, its legislation, financial information, the society participation degree, if the municipality meets the requirements of the Access to Information Law, in summary, whether all these information are available or not. For all these factors, a binary classification was assigned, allocating grades of 0 or 1 , in which 0 is when the particular variable is not present and 1 when it is present, considering that there are criteria for punctuation, which for some variables engages a greater number of perspectives evaluated, resulting in the sum of such panoramas.

Consequently, for each municipality these punctuations were added, to find out the transparency index, which has 75 as the greatest score, which represents the greatest level of transparency, contemplating all the aspects, and the others are considered from this greatest value, taken as reference in the value of 100. This way, the Transparency Index of the Municipal Public Management is classified as Very High, High, Average, Low, and Very Low (MELO; PARRÉ, 2007; PINTO; CORONEL; BENDER FILHO, 2015).

To carry out the data treatment and analysis, the information were analyzed by means of the descriptive statistics, which aims at concentrating conceptions that are equivalent, making it possible to achieve a wider perspective regarding the obtained values, classifying them through graphs, tables and descriptive parameters (GUEDES et al., 
2005). Tests of mean difference are also applied, to contemplate the collected data, and Excel and Statistical Package for the Social Sciences (SPSS) tools were used to analyze information in a more adequate way.

In this way, supported by Cruz et al. (2012)'s study, the Transparency Index of the Municipal Public Management (ITGP-M) was computed by the following model:

$$
\text { ITGP-M= D1+D2+ D3+D4+ D5+ D6+D7+D8+D9+D10+D11 }
$$

Such an equation was computed for all the 497 municipalities to be selected, which belong to Rio Grande do Sul. An analysis among them was carried out, regarding which cover the evaluated dimensions, and which do not cover.

Moreover, to test the variables described in the present study, a multiple linear regression by the Ordinary Leasts Squares (OLS) was carried out, which aimed at identifying the existing association among the explanatory variables, in the case of this investigation, the transparency level (FÁVERO et al., 2009). In this way, the regression was carried out with cross-sectional data, which is defined by the collection of a single variable, or in a greater amount, in the same period, where an analysis on a general regression was carried out (GUJARATI; PORTER, 2012).

For this purpose, the transparency index was employed under the analyzed period, faced with the variables that are able to influence the transparency level. That way, variables are tested to prove they impact in the transparency level of the municipal public management, such a perspective is computed by the following equation:

$$
\begin{gathered}
\text { Y } i=\alpha+\beta 1 \text { economicdevelopment } i+\beta 2 \text { populationgrouth } i+\beta 3 \text { education } i+\beta 4 \text { health } i+\beta 5 \text { municipalrevenue } i+ \\
\beta 6 \text { populationrevenue } i+\beta \text { expenditure } i+\beta 8 \text { consumption } i+\beta 9 \text { municipalage } i+\beta 10 \text { populationage } i+\beta 11 \text { size } i+\mu i
\end{gathered}
$$

Where:

$\mathrm{y}$ is the transparency level;

$i$ represents the researched municipality;

$\alpha$ is the intercept;

$\beta$ is the angular coefficient of the relationship of the regression variables; and

$\mu$ is the term for random or stochastic error.

The other variables exposed in the regression model are presented and explained next, in Table 2. It is important to highlight that the most recent data concerning the variables were used, considering the discovered values in their totality, for each variable of the corresponding influence group.

Table 2. Variables to be tested

\begin{tabular}{lllll}
\hline $\begin{array}{l}\text { Influence } \\
\text { Group }\end{array}$ & Variable & $\begin{array}{l}\text { Expected } \\
\text { relation }\end{array}$ & Author & $\begin{array}{l}\text { Representation in } \\
\text { model }\end{array}$ \\
\hline $\begin{array}{l}\text { Economic } \\
\text { development }\end{array}$ & $\begin{array}{l}\text { Gross Domestic } \\
\text { Product (GDP) }\end{array}$ & Positive & $\begin{array}{l}\text { Cruz et al. (2012); Rodrigues } \\
\text { Júnior and Salgueiro (2015); } \\
\text { Brocco et al. (2018); Fraga et } \\
\text { al. (2019) }\end{array}$ & $\beta$ leconomicdevelopmenti \\
\hline $\begin{array}{l}\text { Population } \\
\text { growth }\end{array}$ & $\begin{array}{l}\text { Municipal Human } \\
\text { Development Index } \\
\text { (MHDI) }\end{array}$ & Positive & $\begin{array}{l}\text { Cruz et al. (2012); Brocco et al. } \\
(2018)\end{array}$ & $\beta 2$ populationgrowthi \\
\hline Education & Schooling rate & Positive & Cruz et al. (2012) & $\beta 3$ educationi \\
\hline Health & $\begin{array}{l}\text { Presence of hospital } \\
\text { and health center }\end{array}$ & Positive & Empirical investigation & $\beta 4$ healthi \\
\hline $\begin{array}{l}\text { Municipal } \\
\text { revenue }\end{array}$ & $\begin{array}{l}\text { Revenue of the Positive } \\
\text { municipality's } \\
\text { current receipts }\end{array}$ & & $\begin{array}{l}\text { Cruz et al. (2012); Queiroz et } \\
\text { al. (2013); Muñoz, Bolívar, }\end{array}$ & $\beta 5$ municipalrevenuei \\
& & $\begin{array}{l}\text { Hernández (2016); Brocco et } \\
\text { al. (2018); Fraga et al. (2019); }\end{array}$ & \\
& & Baldissera et al. (2020) & \\
\hline
\end{tabular}




\begin{tabular}{|c|c|c|c|c|}
\hline $\begin{array}{l}\text { Population } \\
\text { revenue }\end{array}$ & $\begin{array}{l}\text { Population average } \\
\text { income }\end{array}$ & Positive & $\begin{array}{l}\text { Rodrigues Júnior and Salgueiro } \\
\text { (2015); Silva and Bruni (2019) }\end{array}$ & $\beta 6$ populationrevenue $i$ \\
\hline Expenditure & $\begin{array}{l}\text { Municipal } \\
\text { expenditures }\end{array}$ & Negative & $\begin{array}{l}\text { Rodrigues Júnior and Salgueiro } \\
\text { (2015); Baldissera et al. (2020) }\end{array}$ & $\beta 7$ expenditure $i$ \\
\hline Consumption & $\begin{array}{l}\text { Urban consumption } \\
\text { potential }\end{array}$ & Positive & Cruz et al. (2012) & $\beta 8$ consumption $i$ \\
\hline Municipal age & $\begin{array}{l}\text { Municipality's } \\
\text { existing time in years }\end{array}$ & Positive & $\begin{array}{l}\text { Gallego-Álvarez, } \\
\text { Rodríguez-Domínguez, } \\
\text { García-Sánchez (2010) }\end{array}$ & $\beta 9$ municipalage $i$ \\
\hline $\begin{array}{l}\text { Population } \\
\text { age }\end{array}$ & $\begin{array}{l}\text { Elderly population } \\
\text { age ratio }\end{array}$ & Negative & Silva and Bruni (2019) & $\beta 10$ populationage $i$ \\
\hline Size & Municipality’s size & Positive & $\begin{array}{l}\text { Gallego-Álvarez, } \\
\text { Rodríguez-Domínguez, } \\
\text { García-Sánchez (2010); } \\
\text { Queiroz et al. (2013); } \\
\text { Rodrigues Júnior and Salgueiro } \\
\text { (2015); Fraga et al. (2019); } \\
\text { Baldissera et al. (2020) }\end{array}$ & $\beta 11$ size $i$ \\
\hline
\end{tabular}

Source: Authors.

In addition, to verify if the regression data present heteroscedasticity and autocorrelation, the White and Durbin-Watson tests were applied, respectively. In case these aspects are present among data, the regression by the OLS is carried out with consistent standard errors with heteroscedasticity and autocorrelation (VEC) (GREENE, 2008). The software used for the regression estimation will be the Gnu Regression Econometrics and Time-series Library (GRETL).

Thus, the Transparency Index of the Municipal Public Management's usefulness for Rio Grande do Sul state's municipalities is wide, because from this index it is possible to find out which municipalities are following what the Access to Information Law determines, and which are not. That way, the variables that are identified as important for the transparency level also tend to demonstrate to the municipalities why they are more transparent or not, and, with these results, municipal governments may improve their management, have a better communication with society and ensure transparency in the municipal management.

\section{Results}

Rio do Grande do Sul is one of the three states that are part of Brazil's south region, which has 497 municipalities, with Porto Alegre as its capital, bordering the state of Santa Catarina, Argentina, Uruguay and the Atlantic Ocean. The total population, in the 2010 census, was represented by 10.693 .929 inhabitants, characterizing 37,96 inhabitants $/ \mathrm{km}^{2}$, since its territorial extension is $281.707,151 \mathrm{~km}^{2}$ (IBGE, 2020).

In order to provide progress for the state regions, ensuring that it was suitable, in 1994 the state was separated into 28 distinct zones, classified as Regional Development Councils (Conselhos Regionais de Desenvolvimento - Coredes), concerning the insurance of the correct division of assets for all regions (RIO GRANDE DO SUL GOVERNMENT, 2017). This new distribution also aims to develop the life quality of citizens, ensuring their conservation in their localities, also observing the reestablishment of the regions' ecosystem (PESSOA, 2017).

Based on this, the present study analyzed the Public Management Transparency Index in the municipalities of Rio Grande do Sul state, which has a maximum value of 100 that should be presented by the municipality, analyzing different perspectives concerning accountability, disclosure of information, participation of society, observing the importance of transparency in the municipal issue. Thus, firstly, the descriptive statistics of the Transparency Index of the Municipal Public Management (ITGP-M) was considered, computing the average of indexes obtained by the municipalities, the standard deviation, in addition to the maximum and minimum values reached, all of which these values are shown in Table 3. 
Table 3. ITGP-M descriptive statistics

\begin{tabular}{ll}
\hline Descriptive Statistics & Values \\
\cline { 2 - 3 } Average & 63,47 \\
\cline { 2 - 2 } Standard deviation & 9,46 \\
\cline { 2 - 2 } Maximum & 93,42 \\
\cline { 2 - 2 } Minimum & 35,53 \\
\hline
\end{tabular}

Source: Authors.

It can be seen on Table 1, through descriptive statistics of the present study, that the average of the ITGP-M values totalled 63.47, a significant value distant from the maximum observed index of the municipality, which reached the value of 93.42. The minimum index observed through the analysis of the ITGP-M in Rio Grande do Sul's municipalities was 35.53 , and the analysis presented the value of 9.46 as a standard deviation.

In order to clearly and appropriately classify the ITGP-M, allowing a more appropriate conception for each municipality, the values obtained are related based on a scale ranging from very high to very low, and such classification is based on the methodology adopted in the studies by Melo and Parré (2007), and Pinto, Coronel and Bender Filho (2015), and this division occurs through the mean values of transparency and their standard deviation. Thus, aiming at a better visualization and explanation about the criteria, the values and the designation of the ITGP-M, these questions are exposed below, in Table 4.

Table 4. ITGP-M classification

\begin{tabular}{lll}
\hline Criteria adopted & Score & Classification \\
\hline Mean plus 2 standard deviations & $\mathrm{I} \geq 82,39$ & Very high \\
\hline Mean plus 1 standard deviation & $72,93 \leq \mathrm{I}<82,39$ & High \\
\hline Mean & $54,01 \leq \mathrm{I}<72,93$ & Average \\
\hline Mean less 1 standard deviation & $44,55 \leq \mathrm{I}<54,01$ & Low \\
\hline Mean less 2 standard deviations & $\mathrm{I}<44,55$ & Very low \\
\hline
\end{tabular}

Source: Melo and Parré (2007); Pinto, Coronel and Bender Filho (2015).

From what is shown in Chart 3, it can be observed that the classification considered as very high refers to values greater than 82.39; the high rating refers to the lower values that are between 72.93 and 82.39; the average classification is in relation to values ranging from 54.01 to 72.93 , and this classification tends to include most municipalities, as their interval is the largest presented in the classification. The low classification deals with values between 44.55 and 54.01; and very low is when the municipality has an index below 44.55 . All of these values were calculated taking into account the indexes average achieved by the municipalities, adding or decreasing the value of the standard deviation.

Thereby, the municipalities of Rio Grande do Sul state have different classifications, where there are disparities in the order of their transparency indexes, with some classifications presenting a larger number of municipalities. This fact can be seen in Table 5, below

Table 5. Quantification of municipalities by classification

\begin{tabular}{lll}
\hline Classification & Amount & Percentage (\%) \\
\hline Very high & 5 & 1,01 \\
\hline High & 75 & 15,09 \\
\hline Average & 329 & 66,20 \\
\hline
\end{tabular}




\begin{tabular}{lll}
\hline Low & 69 & 13,88 \\
\hline Very low & 19 & 3,82 \\
\hline Total & 497 & 100 \\
\hline
\end{tabular}

Source: Authors.

Based on Table 5, it is possible to observe that most municipalities in Rio Grande do Sul have an average transparency index, totaling 329 locations, representing 66.20\%, then 75 municipalities have ITGP-M considered high, where the they represent $15.09 \%$ of the total, in addition, 69 cities have a low transparency index, being $13.88 \%$. It is also noteworthy that 19 municipalities have a very low classification, totaling $3.82 \%$, and only five municipalities have a high classification regarding the ITGP-M, characterizing only $1.01 \%$.

In addition, many municipalities that have an obligation to comply with transparent aspects, disclosing all information related to public management, are not performing this task. Thus, Table 6 presents the municipalities that have more than 10,000 inhabitants, that is, those that are required to comply with the Access to Information Law, but that have a low or very low ITGP-M.

Table 6. Municipalities with more than 10 thousand inhabitants with low or very low ITGP-M

\begin{tabular}{llll}
\hline Municipalities & Corede belonging & ITGP-M & Classification \\
\hline Arroio do Sal & Litoral & 53,95 & Low \\
\hline Caxias do Sul & Serra & 53,95 & Low \\
\hline Nonoai & Médio Alto Uruguai & 53,95 & Low \\
\hline Santa Vitória do Palmar & Sul & 53,95 & Low \\
\hline São Borja & Fronteira Oeste & 53,95 & Low \\
\hline São Francisco de Assis & Vale do Jaguarí & 53,95 & Low \\
\hline Itaqui & Fronteira Oeste & Low \\
\hline Lajeado & Vale do Taquari & 52,63 & Low \\
\hline Novo Hamburgo & Vale do Rio dos Sinos & 52,63 & Low \\
\hline Santa Cruz do Sul & Vale do Rio Pardo & 52,63 & Low \\
\hline Santo Antônio da Patrulha & Metropolitano Delta do Jacuí & 52,63 & Low \\
\hline São Gabriel & Fronteira Oeste & 52,63 & Low \\
\hline Seberi & Médio Alto Uruguai & 52,63 & Low \\
\hline Terra de Areia & Litoral & 52,63 & Low \\
\hline Marau & Produção & 51,32 & Low \\
\hline Santo Cristo & Fronteira Noroeste & 50,00 & Low \\
\hline Capela de Santana & Vale do Caí & 38,16 & Very low
\end{tabular}

Source: Authors.

On Table 3 it was identified that although only municipalities with less than 10 thousand inhabitants are exempted from disclosing information on their transparency portals, determined by the $\S 4$ of the Access to Information Law, larger municipalities do not comply with the mandatory disclosure requirement, and have unsatisfactory levels of transparency, going against what is legally provided for (BRASIL, 2011). Thus, considering the 167 municipalities that have a duty to fully comply with the transparent aspects, 17 have low or very low levels of transparency, characterizing $10.18 \%$ of the municipalities that, despite being obliged, do not carry out the disclosure of information.

Thus, there are still difficulties concerning the determinations of the Access to Information Law, especially with 
regard to municipalities, because, even with the obligation, they are not disclosing their information, there is a very low probability for them to adopt behaviors that are not related to legal determinations. So, the causes of this fact are the neglect of public managers, lack of administrative competence, lack of responsibility to publish information, inexistence of a technological apparatus or the indifference of citizens regarding the use of information (MICHENER, 2016; MACEDO et al., 2020).

There are several issues that can influence the transparency observed in a municipality, which are strictly related to the public management and the population of the analyzed location. To this end, the perspectives on economic and population development, education, health, municipal and population revenue, expenditure, consumption, population and municipal age, as well as the size of the municipalities were analyzed, observing whether all these issues influence on the weighted ITGP-M, and the results found are shown in Table 7.

Table 7. Explanatory variables of the ITGP-M

\begin{tabular}{llll}
\hline Variable & Coefficient & t-ratio & p-value \\
\hline GDP & 0,0366 & 0,27 & 0,7805 \\
\hline MHDI & 0,4270 & 2,52 & $0,0121^{* *}$ \\
\hline Schooling rate & $-0,3696$ & $-2,04$ & $0,0416^{* *}$ \\
\hline Presence of hospital or health center & 0,0393 & 0,08 & 0,934 \\
\hline Collection of current revenues & 0,2782 & 0,27 & 0,7868 \\
\hline Population average income & 0,03838 & 0,42 & 0,6752 \\
\hline Municipal expenditure & $-0,2852$ & $-2,19$ & $0,029^{* *}$ \\
\hline Urban Consumption Potential & $-2,3267$ & $-1,49$ & 0,1348 \\
\hline Municipality age & 0,0156 & 0,36 & 0,7217 \\
\hline Elderly population age ratio & $-0,1753$ & $-2,39$ & $0,0174^{* *}$ \\
\hline Municipality size & 2,3665 & 1,91 & $0,0564 *$ \\
\hline
\end{tabular}

Source: Authors.

Note: Values with two asterisks $(* *)$ denote significant coefficients at the level of $5 \%$ and with an asterisk $(*)$ denote significant coefficients at the level of $10 \%$.

Considering the eleven variables analyzed, only five showed significance, that is, they have the capacity to influence the transparency indexes of the municipalities of Rio Grande do Sul. Such variables are the Municipal Human Development Index (MHDI), Schooling rate, Expenditure of the municipality, Elderly population age ratio and Size of the municipality, where the latter presented a significance of $10 \%(0.1)$, with an increased criterion, although its relationship tends not to be fully consistent with the other variables that presented a significance of $5 \%(0.05)$.

Therefore, it is inferred that both the MHDI and the size of the municipality have a positive impact on the ITGP-M observed in the municipalities of the state, that is, the higher the MHDI values and the larger the size of the municipality, the greater the level of transparency presented. The Schooling rate, Municipal expenses and the lderly population age ratio had a negative impact compared to the ITGP-M contemplated in Rio Grande do Sul, explaining that the higher the values of such variables, the lower the levels of transparency within these realities.

These conceptions can be observed in previous studies carried out, in which the fact of MHDI presenting a positive association with the observed transparency can be reinforced, based on the study by Cruz et al. (2012), which highlights this favorable relation between the two aspects. Concerning the size of the municipalities, when it is found that its impact is positive in the view of the transparency index, this issue can also be observed in the studies by Fraga et al. (2019) and Baldissera et al. (2020).

In relation to the schooling rate presented, its relationship with transparency is negative, which the study by Müller et al. (2020) also attests, indicating that individuals who have a higher level of education do not demonstrate the necessary attention in the face of transparency. The expenditure aspects and the elderly population age ratio, in turn, have a negative relation with the ITGP-M, going in the opposite direction to the results obtained in the studies by 
Baldissera et al. (2020) and Silva and Bruni (2019), respectively.

Therefore, it is inferred that, when carrying out the analysis in order to identify which variables had an impact on the transparency index, it was found that not all variables are able to intervene in the results obtained, and when they have influence, it can be both positive, as negative, demonstrating that public transparency is a phenomenon that presents differences in relation to the localities analyzed and that evolves over time. That said, it is well known that transparency is something fundamental for public management, bringing greater clarity to everyone about what has been accomplished, requiring greater attention and commitment to comply with this scenario.

\section{Conclusions}

Considering the analysis of the most recent data published in the municipal transparency portals, through the measurement of transparency in Rio Grande do Sul, identifying the level presented by the state's municipalities, based on the Transparency Index of the Municipal Public Management (ITGP- M), it was noticed that most municipalities in the state have an average performance in terms of meeting the dimensions related to transparency. Furthermore, it is noticeable that many municipalities, in addition to failing to disclose much information that is relevant, end up erroneously externalizing some data, even publishing it in a wrong way, where contradictory data are found, which have no basis or coherence.

Hereupon, it is still evident that municipalities in Rio Grande do Sul, located in the same region, have distant, significantly different levels of transparency, which points out that the region in which the municipality is located tends not to influence the observance of transparency.

Nevertheless, with the analysis of the transparency portals of the municipalities of Rio Grande do Sul, it was possible to identify that they have the necessary tools for the dissemination of information to the entire population, but they do not do so, as indicated, which limits the participation of individuals in the face of the decisions that public management must take. Many municipalities fail to expose their data, showing disinterest and lack of concern in complying with the requirements imposed by transparency, which ends up aggravating the concern about the information that is hidden, which is unknown to those who have an interest.

Therefore, when trying to identify which variables explain the level of transparency of the municipalities in the state of Rio Grande do Sul, it is noticed that only five variables have the capacity to influence the transparency indexes of the municipalities in Rio Grande do Sul, which are the Municipal Human Development Index (MHDI), school enrollment rate, municipality expenses, proportion of elderly population and the size of the municipality. As for their relationship with the index, the MHDI and the size of the municipality have a positive impact on transparency, demonstrating that the higher the MHDI values and the larger the municipality, the greater the level of transparency presented by the municipality.

Therefore, when trying to identify which variables explain the level of transparency of the municipalities in the state of Rio Grande do Sul, it is noticed that only five variables have the capacity to influence the transparency indexes of the municipalities in Rio Grande do Sul, which are the Municipal Human Development Index (MHDI), school enrollment rate, municipality expenses, elderly population age ratio and the size of the municipality. As for their relationship with the index, the MHDI and the size of the municipality have a positive impact on transparency, demonstrating that the higher the MHDI values and the larger the municipality, the greater the level of transparency presented by the municipality.

The schooling rate, expenses and the elderly population age ratio, on the other hand, has a negative impact in relation to the observed transparency index. Thus, the greater the education of individuals, the greater the expenses of the municipality, and the older the population, the lower the levels of transparency manifested by the municipalities of Rio Grande do Sul.

It can be seen, from the analysis carried out, that the municipalities of Rio Grande do Sul still need to evolve in terms of the perspectives concerning transparency, starting to demonstrate their information, publishing it so that the whole society can access and monitor the progress in public management. In this way, municipalities can hire specific people or companies to control and publish the information on their transparency portals, they can previously organize the data that needs to be explained, they have to plan how the information will be exposed and check all the issues that involve them before its publication.

Based on what was accomplished in the present study, his theories affirm an improvement of the method that was used, being that it was obtained, new and different variables, bringing a new classification and calculation for the transparency index, besides contributing with the fact of identifying other variables that came to explain the standardization. In the same way, the practical implications obtained in this study are improve the reality of 
transparency in some locations that have lower levels of transparency, such as the Capela de Santana, which has a transparency index considered to be very low; aspects such as schooling rate, municipal expenditure and urban consumption potential, which showed a negative relationship with the observed transparency, can be explored in a more appropriate way and improved by the managers; and improve the transparency portals and the quality of the information made available to them.

In view of all this, it is observed that the present study has some limitations, such as analyzing only the state of Rio Grande do Sul, with no characterization of the regions of the state through the observed transparency, investigating only eleven socioeconomic variables, not detailing the complexity of transparency. Therefore, it is suggested, for future studies, an analysis that encompasses a regional perspective in Rio Grande do Sul, exploring more the regions of the state, observing how their level of transparency is found, checking other variables that tend to impact on the transparency index of the municipalities and observing other aspects in the transparency portals, an investigation that could be carried out together with public managers.

\section{References}

Araújo, C. da L. B. D., \& Maia, L. C. G. (2014). Gestão pública e governo eletrônico: Estudo sobre Sítios institucionais de prefeituras no estado de Minas Gerais. Revista Democracia Digital e Governo Eletrônico, 1(10), 76-103.

Baldissera, J. F., Dall'Asta, L., Casagrande, L. F., \& Oliveira, A. M. B. D. (2020). Influência dos aspectos socioeconômicos, financeiro-orçamentários e político-eleitorais na transparência dos governos locais. Revista de Administração Pública, 54(2), 340-359. https://doi.org/10.1590/0034-761220190048

Barros, C. da C., Barros, F. M. da C., Souza, F. J. V. D., Batista. E. M., \& Câmara, R. P. de B. (2017). Transparência na gestão pública: um estudo do atendimento dos municípios do estado Rio Grande do Norte a lei complementar no 131/2009. Revista Ambiente Contábil, 9(2), 200-221.

Brasil. (1988). Constituição da República Federativa do Brasil de 1988. Retrieved September 21, 2020, from http://www.planalto.gov.br/ccivil_03/constituicao/constituicao.htm

Brasil. (2011). Lei $n^{\circ}$ 12.527, de 18 de novembro de 2011, que regula o acesso a informações previsto no inciso XXXIII do art. $5^{\circ}$, no inciso II do $\S 3^{\circ}$ do art. 37 e no $\S 2^{\circ}$ do art. 216 da Constituição Federal. Retrieved July 23, 2020, from http://www.planalto.gov.br/ccivil_03/_ato2011-2014/2011/lei/112527.htm

Brocco, C., Grando, T., Martins, V. de Q., Brunozi Junior, A. C., \& Corrêa, S. (2018). Transparência da gestão pública municipal: fatores explicativos do nível de transparência dos municípios de médio e grande porte do Rio $\begin{array}{llllll}\text { Grande do Sul. Revista Ambiente } & \text { Contábil, } & \text { 10(1), } & \text { 139-159. }\end{array}$ https://doi.org/10.21680/2176-9036.2018v10n1ID12040

Cechinel, A., Fontana, S. A. P., Giustina, K. P. D., Pereira, A. S., \& Prado, S. S. D. (2016). Estudo/análise documental: Uma revisão teórica e metodológica. Revista do Programa de Pós-Graduação em Educação-UNESC, 5(1), 1-7. https://doi.org/10.18616/ce.v5i1.2446

Comin, D., Ramos, F. M., Zucchi, C., Favretto, J., \& Fachi, C. C. P. (2016). A transparência ativa nos municípios de Santa Catarina: Avaliação do índice de atendimento à lei de acesso à informação e suas determinantes. Revista Catarinense da Ciência Contábil, 15(46), 24-34. https://doi.org/10.16930/2237-7662/rccc.v15n46p24-34

Controladoria Geral da União. (2020). Portal da transparência. Retrieved February 17, 2020, from http://www.portaltransparencia.gov.br/

Cruz, C. F., Ferreira, A. C. de S., Silva, L. M. D., \& Macedo, M. A. da S. (2012). Transparência da gestão pública municipal: um estudo a partir dos portais eletrônicos dos maiores municípios brasileiros. Revista de Administração Pública, 46(1), 153-176. https://doi.org/10.1590/S0034-76122012000100008

Cruz, N. F. D., Tavares, A. F., Marques, R. C., Jorge, S., \& Sousa, L. D. (2015). Measuring local government transparency. Public Management Review, 18(6), 1-39. https://doi.org/10.1080/14719037.2015.1051572

Fávero, L. P., Belfiore, P., Silva, F. D., \& Chan, B. L. (2009). Análise de dados: modelagem multivariada para tomada de decisões. Rio de Janeiro: Elsevier.

Fraga, L. dos S., Medeiros, A. P. D., Vieira, K. M., \& Bender Filho, R. (2019). Transparência da gestão pública: Análise em pequenos municípios do Rio Grande do Sul. Revista Gestão e Planejamento, 20, 255-272. https://doi.org/10.21714/2178-8030gep.v20.4731

Franco, L. M. G., Rezende, D. A., Figueiredo, F. de C., \& Nascimento, C. D. (2014). Nível de divulgação eletrônica 
da contabilidade pública dos municípios do Paraná no ambiente da internet. Revista de Ciências da Administração, 16(38), 140-153. https://doi.org/10.5007/2175-8077.2014v16n38p140

Franke, L. L. M., Visentini, M. S., Söthe, A., \& Santos, M. D. (2020). A transparência pública nos municípios integrantes do Corede/Missões-RS e sua relação com os indicadores socioeconômicos. Revista Práticas de Administração Pública, 4(1), 40-62. https://doi.org/10.5902/2526629242806

Gabriel, M. L. D. (2014). Métodos Quantitativos em Ciências Sociais: Sugestões para Elaboração do Relatório de Pesquisa. Desenvolvimento em Questão, 12(28), 348-369. https://doi.org/10.21527/2237-6453.2014.28.348-369

Gallego-Álvarez, I., Rodríguez-Domínguez, L., \& García-Sánchez, I. M. (2010). Are determining factors of municipal E-government common to a worldwide municipal view? An intra-country comparison. Government Information Quarterly, 27, 423-430. https://doi.org/10.1016/j.giq.2009.12.011

Gerhardt, T. E., \& Silveira, D. T. (2009). Métodos de pesquisa. Porto Alegre: Editora da UFRGS.

Gomes, F. R., Freire, R. de S., \& Sales, J. D. A. (2017). Transparência pública em portais de institutos de previdência municipais da Paraíba: A accountability foi esquecida?. RIC-Revista de Informação Contábil, 11(2), 52-68.

Goulart, J. L., Troian, A., \& Quispe, J. N. (2020). Observatórios sociais e sua importância para a gestão pública na região sul do Brasil. Revista Desenvolvimento em Questão, 18(51), 113-128. https://doi.org/10.21527/2237-6453.2020.51.113-128

Governo do Estado do Rio Grande do Sul. (2017). Sobre o RS. Retrieved March 30, 2020, from https://estado.rs.gov.br/sobre-o-rs

Greene, W. H. (2008). Econometric analysis. New Jersey: Prentice Hall.

Guedes, T. A., Acorsi, C. R. L., Martins, A. B. T., \& Janeiro, V. (2005). Estatística Descritiva. Retrieved April 8, 2020, from http://www.each.usp.br/rvicente/Guedes_etal_Estatistica_Descritiva

Gujarati, D. N., \& Porter, D. C. (2011). Econometria básica. Porto Alegre: AMGH.

Hair, Jr. J. F., Babin, B., Money, A. H., \& Samouel, P. (2005). Fundamentos de métodos de pesquisa em administração. Porto Alegre: Bookman.

Instituto Brasileiro de Geografia e Estatística. (2020). Rio Grande do Sul-Panorama. Retrieved March 30, 2020, from https://cidades.ibge.gov.br/brasil/rs/panorama

Lobo, A. S. M., \& Maia, L. C. G. (2015). O uso das TICs como ferramenta de ensino-aprendizagem no Ensino Superior. Caderno de Geografia, 25(44), 16-26. https://doi.org/10.5752/P.2318-2962.2015v25n44p16

Macedo, S. V., Valadares, J. L., Ribeiro Filho, W. F., \& Silva Júnior, A. C. D. (2020). Transparência local: Implicações da Lei de Acesso à Informação em municípios mineiros. Sociedade, Contabilidade e Gestão, 15(2), 100-117.

Mello, J. G. D., Oliveira, P. de A., \& Pinto, N. G. M. (2017). Governança Pública: uma análise das publicações mundiais entre os anos de 2006 e 2015. Observatorio de La Economía Latino-Americana, 1-22.

Melo, C. O. D., \& Parré, J. L. (2007). Índice de desenvolvimento rural dos municípios paranaenses: determinantes e hierarquização. Revista de Economia e Sociologia Rural, 45(2), 329-365. https://doi.org/10.1590/S0103-20032007000200005

Michener, G. (2016). Transparência Local no Brasil: Avaliando a aplicação da Lei de Acesso nos estados e nas grandes cidades. Rio de Janeiro: FGV e Open Society Foundations.

Michener, G., Moncau, L. F. M., \& Velasco, R. (2014). Estado brasileiro e transparência: avaliando a aplicação da Lei de Acesso à Informação. Rio de Janeiro: FGV e Open Society Foundations.

Molinari, A. P., \& Clazer, E. A. (2015). Índices de transparência: Um estudo nos municípios que compõem a AMCESPAR. Proceedings of the Congresso Internacional de Administração, Ponta Grossa/PR, Brasil.

Müller, A. P., Züge, A. A., Klein, L. L., Vieira, K. M., \& Pinto, N. G. M. (2020). Percepção da transparência pública municipal: interesse dos cidadãos. Research, Society and Development, 9(9), 1-26. https://doi.org/10.33448/rsd-v9i9.6835

Muñoz, L. A., Bolívar, M. P. R., \& Hernández, A. M. L. (2016). Transparency in governments: a meta-analytic review of incentives for digital versus hard-copy public financial disclosures. American Review of Public Administration, 47(5), 550-573. https://doi.org/10.1177/0275074016629008 
Pessoa, M. L. (2017). Atlas FEE. Porto Alegre: FEE. Retrieved 30 March, 2020, from http://atlas.fee.tche.br/rio-grande-do-sul/

Piña, G., \& Avellaneda, C. (2019). Central government strategies to promote local governments' transparency: Guidance or enforcement?. Public Performance \& Management Review, 42(2), 357-382. https://doi.org/10.1080/15309576.2018.1462215

Pinto, N. G. M., Coronel, D. A., \& Bender Filho, R. (2015). Eficiência no desenvolvimento regional resultante do Programa Bolsa Família: Aplicação da Análise Envoltória de Dados (DEA) nos estados e regiões brasileiras de 2004 a 2010. Revista Desenvolvimento em Questão, 13(31), 143-172. https://doi.org/10.21527/2237-6453.2015.31.143-172

Pires, A. M., Scherer, F. L., Santos, M. B. D., \& Carpes, A. de M. (2013). Transparência da gestão pública municipal: Um estudo dos municípios de Santa Maria e Novo Hamburgo/RS. Revista Estudos do CEPE, (38), 131-160.

Queiroz, D. B. D., Nobre, F. C., Silva, W. V. D., \& Araújo, A. O. (2013). Transparência dos municípios do Rio Grande do Norte: Avaliação da relação entre o nível de disclosure, tamanho e características socioeconômicas. Revista de Evidenciação Contábil \& Finanças, 1(2), 38-51. https://doi.org/10.18405/recfin20130203

Raupp, F. M., \& Pinho, J. A. G. D. (2020). Precisamos evoluir em transparência? Uma análise dos estados brasileiros na divulgação de informações sobre a COVID-19. Revista Eletrônica Gestão \& Sociedade, 14(39), 3725-3739. https://doi.org/10.21171/ges.v14i39.3253

Ribeiro, C. P. de P., Pereira, A. D. S., Silva, E. A. D., \& Faroni, W. (2011). Difusão da informação na administração pública. Revista TransInformação, 23(2), 159-171. https://doi.org/10.1590/S0103-37862011000200006

Rodrigues Júnior, M. S., \& Salgueiro, V. A. de G. (2015). Transparência na gestão fiscal nos municípios do estado do Ceará. Revista Controle-Doutrina e Artigos, 13(1), 47-63. https://doi.org/10.32586/rcda.v13i1.21

Santos, L. N. D., \& Rocha, J. S. (2019). A importância da transparência para o fortalecimento da gestão pública democrática. Id on Line-Revista Multidisciplinar e de Psicologia, 13(44), 892-904. https://doi.org/10.14295/idonline.v13i44.1661

Siche, R., Agostinho, F., Ortega, E., \& Romeiro, A. (2007). Índices versus indicadores: Precisões conceituais na discussão da sustentabilidade de países. Revista Ambiente e Sociedade, 10(2), 137-148. https://doi.org/10.1590/S1414-753X2007000200009

Silva, W. A. de O. E., \& Bruni, A. L. (2019). Variáveis socioeconômicas determinantes para a transparência pública passiva nos municípios brasileiros. Revista de Administração Pública, 53(2), 415-431. https://doi.org/10.1590/0034-761220170383

Tejedo-Romero, F., \& Araujo, J. F. F. E. (2018). Transparencia em los municipios españoles: determinantes de la divulgación de información. Convergencia: Revista de Ciencias Sociales, (78), 153-174. https://doi.org/10.29101/crcs.v25i78.9254

Visentini, M. S., \& Santos, M. D. (2019). Transparência na Gestão Pública Municipal evidenciada nos portais eletrônicos dos municípios do Conselho Regional de Desenvolvimento (Corede) das Missões/RS. Revista Desenvolvimento em Questão, 17(49), 158-175. https://doi.org/10.21527/2237-6453.2019.49.158-175

Zuccolotto, R., \& Teixeira, M. A. C. (2014). As causas da Transparência Fiscal: Evidências nos Estados Brasileiros. Revista Contabilidade e Finanças, 25(66), 242-254. https://doi.org/10.1590/1808-057x201410820

Zuccolotto, R., \& Teixeira, M. A. C. (2019). Transparência: Aspectos conceituais e avanços no contexto brasileiro. Brasília: Enap.

\section{Copyrights}

Copyright for this article is retained by the author(s), with first publication rights granted to the journal.

This is an open-access article distributed under the terms and conditions of the Creative Commons Attribution license (http://creativecommons.org/licenses/by/4.0/). 